Brandeis | цввая

brandeis.edu/j-caste
CASTE: A Global Journal on Social Exclusion

Vol. 2 No. 2 pp. 28 I-294

October-November 2021

ISSN 2639-4928

https://doi.org/10.26812/caste.v2i2.338

\title{
Reading Dalit Autobiographies in English: A Top Ten List
}

\author{
Christopher Queen'
}

\begin{abstract}
Dalit autobiography has joined protest poetry as a leading genre of Dalit Literature since the nineteen seventies. Finding their inspiration in the social and political activism of B. R.Ambedkar (I89|-1956), leader of the India's anticaste movement and a founding father of the Republic, low caste men and women have documented their struggles and victories in the face of ongoing violence and deprivation. Surveying ten life narratives translated into English from Marathi, Hindi, and Kannada, the essay treats works by Ambedkar, Daya Pawar, Sharankumar Limbale, Baby Kamble, Laxman Gaikwad, Siddhalingaiah, Omprakash Valmiki, Urmila Pawar, Vasant Moon and Namdeo Nimgade. Tracing the origins of Dalit autobiography in the writings of Siddharth College and Milind College students in the 1950s, protest writers in the 1960s, and the Dalit Panthers and their followers in the 1970s, the survey identifies recurring themes of social exclusion, poverty, patriarchy, survival and assertion in the realms of politics, employment, education, and religion. These intimate testimonials share a radical vision of social transformation across caste, class, gender, linguistic and geographic boundaries and provide a needed corrective to mainstream portraits of modern Indian social history.
\end{abstract}

\section{Keywords}

Dalit Literature, Dalit autobiography, B. R. Ambedkar, anti-caste movement, Dalit Panthers, Dalit Sahitya

\section{Introduction}

In 1987 I slept on the sofa in Vasant and Meenakshi Moon's apartment in Government Colony, Bandra East, Mumbai. The Moons, both writers and activists in the anti-caste movement launched by Dr. B. R. Ambedkar in the1920s, were

\footnotetext{
'Harvard University, Cambridge, Massachusetts,

E-mail: csqueen@outlook.com
}

(C) 202I Christopher Queen.This is an open access article distributed under the terms of the Creative Commons Attribution License, which permits unrestricted use, distribution, and reproduction in any medium, provided the original author(s) and source are credited. 
kind to host a first-time visitor to India who was eager to learn about the movement and its leaders. In the apartment I saw a brass statue of the Buddha and a charcoal image of Ambedkar taped to the wall. Visiting that morning was a peaceful woman with a shaved head and the ochre robes of a nun. Mr. Moon told me later that she was a friend of Meenakshi's who had entered the Buddhist order after years of being beaten by her husband. I learned that movement members and people with problems dropped by the Moons' house all the time.

The next morning Moon took me on his daily commute on the city bus - an hour of deafening traffic and choking fumes - to Mantralaya, the state office building where he was editing the writings and speeches of Ambedkar. And the following weekend he took me to Nagpur, his hometown, to see the parade ground where Ambedkar led 380,000 of Maharashtra's poorest citizens into Buddhism on October 14,1956 . We visited the private library of books, periodicals, and papers of the Dalit freedom movement that Moon had built above the house he left to his daughter and her husband, a medical doctor, and their first child. The library had four divisions: "A" for Ambedkar, "B" for Buddhism, "C" for Caste, and "D" for Dalit.

Years later the memories of this and subsequent visits to Mumbai, Nagpur, and other centers of Dalit protest, religious conversion, and literary activity were still vivid in my mind as I read Vasant Moon's new memoir, Growing Up Untouchable in India: A Dalit Autobiography $(2001)^{1}$ and the book of reflections and interviews of female Dalit activists that Meenakshi Moon collected with Urmila Pawar, We Also Made History: Women in the Ambedkarite Movement (2008). ${ }^{2}$ Reading these volumes reminded me of the friendships I had made over the years in my deepening engagement with the movement. Moon's autobiography, originally titled Vasti (Neighborhood) in Marathi, was translated into English by Gail Omvedt, a renowned American scholar of caste studies who moved to India in the 1970s. It was introduced by Eleanor Zelliot, Carleton College historian, widely regarded as the leading authority on Ambedkar and the Dalit movement in Maharashtra. It was Professor Zelliot who first introduced me to the Moons and other leaders as she helped generations of scholars, students, and readers to understand the nature and importance of the movement. We traveled together in India and visited each other's classrooms in the States. In 2013, Gail Omvedt came to Harvard to lecture in my class and to meet university students and Ambedkarite activists living in the area. ${ }^{3}$

My first visit to India was cut short by an illness that arrived as I attended a massive wedding with Mr. Moon in Nagpur. The vice mayor of the city and his bride, both Dalit Buddhists, were taking vows before hundreds of dignitaries of all caste backgrounds. I returned to my hotel and then to Boston where I recovered. But I had missed interviews arranged by Moon with ex-untouchable teachers, social workers, and government officials who would still be village servants and scavengers were it not for the educational and employment opportunities guaranteed by the Indian Constitution, the Constitution drafted by India's first law minister, B. R. Ambedkar.

${ }^{1}$ Vasant Moon. (2001). Growing up Untouchable in India: A Dalit autobiography. Lanham, MD: Rowman \& Littlefield.

${ }^{2}$ Urmila Pawar and Meenakshi Moon. (2008). We also made history: Women in the Ambedkarite movement. New Delhi: Zubaan.

${ }^{3}$ Dr. Gail Omvedt passed away on August 24, 2021. This article is dedicated to her memory. 
When I returned home, I found an urgent message from Professor Zelliot. I must attend the wedding of Rekha Nimgade, niece of Meenakshi Moon, which was to happen the next week in Boston! But sadly, I was too weak to attend. Only later did I meet the entire Nimgade family in the U.S. and India and accept the honor of writing the foreword to the lively narrative of Dr. Namdeo Nimgade, father of the bride and husband of Hira, Meenakshi's older sister: In the Tiger's Shadow: The Autobiography of an Ambedkarite (2010). ${ }^{4}$

Given this background you will understand some of the seeds of my passion for reading Dalit autobiographies, life narratives, memoirs, testimonia - all of these terms have been used by scholars - and for trying to hear their message to readers of vastly different backgrounds. For Dalit Sahitya or Dalit literature purports to be a different kind of writing, not to be judged by standards of stylistic originality, beauty, or entertainment, but by its authenticity and truthfulness to the physical, social, psychological and spiritual realities of its narrators and their communities, and to the commitment to a radical vision of social transformation these authors share with one another across caste, class, gender, linguistic and geographic boundaries. I have pored over, marked the pages, and returned to re-read a dozen of these works. I have experienced anger and sadness imagining the grim settings and humiliations of these writers - and also joy when their indomitable spirit transcended the circumstances. Happily for international readers, as Dalit writers continue to record and publish their life narratives, the supply of English originals and translations do not appear to be slackening.

In this survey, we begin with a sketch of the origins of Dalit autobiography in the writing of Ambedkar and the stream of titles that followed the appearance of the Dalit Panthers and Dalit Sahitya in the 1970s. Then we turn to a sampling of this literature, calling your attention to ten titles I have found to be significant in revealing the experience of Dalits in India from before Independence up to the present - and earning, by their earnestness and literary quality, my allegiance to their cause. In these citations, I will try to illustrate themes that recur in these texts-exclusion, poverty, patriarchy, education, assertion, politics, and religion. My hope is that this article and its bibliography will serve as an invitation to those who wish to explore this territory more fully.

While there have been Indian autobiographies and novels depicting the life of low caste communities by upper caste writers dating back a hundred years - most notably Untouchable (English, 1935) by Mulk Raj Anand-no one from untouchable communities before the 1970s had the training, courage, and resources to describe their suffering and aspirations in longform writings and to have them published. In the nineteenth century, the Dalit reformer Mahatma Jyotiba Phule (1828-1890) wrote to an upper caste literary association asking how these writers "with their heads in the clouds" were capable of expressing the feelings and experiences of Dalits. In the 1920s the young B. R. Ambedkar (1891-1956) started fortnightly journals to host Dalit writing on issues of politics, education, and culture: Mooknayak, "Leader of the Voiceless" (1920) and Bahishkrit Bharat, "Untouchable India" (1927). Around 1935,

${ }^{4}$ Namdeo Nimgade. (2010). In the tiger's shadow: The autobiography of an Ambedkarite. New Delhi: Navayana. 
when Ambedkar announced he would leave Hinduism for a religion offering human dignity and freedom, he penned a memoir of his early experiences as a Dalit which remained buried in his papers until after his death.

Inspired by Ambedkar's published writings and activism, students of Siddharth College, founded in Bombay by Ambedkar in 1945, started the literary society Siddharth Sahitya Sangh to explore how their lives and problems were different from those of the upper castes and whether these issues can be expressed in literature. In 1958 after Ambedkar's death, these writers and friends renamed their group the Maharashtra Dalit Sahitya Sangh and organized the first public conference of Dalit writers in Bombay. They passed a resolution that "the literature written by Dalits and that written by others about the Dalits in Marathi be accepted as a separate entity known as 'Dalit literature,' and realizing its cultural importance the universities and literary organizations should give it its proper place."

The 1960s saw the appearance of the Little Magazine movement - a vehicle for poets like Baburao Bagul and other "angry young men" to publish protest poetry and stories directed at the injustices of the caste system. In 1968, Dr. Gangadhar Pantawane (1937-2018), a graduate of Milind College (founded by Ambedkar) and Marathwada University (renamed Dr. Babasaheb Ambedkar University after a long fight which Pantawane helped to lead) founded the pioneering literary journal Asmitadarsh, which published Dalit writings for five decades under his leadership. ${ }^{5}$

Yet none of these precursors attracted the flurry of interest and controversy that marked the founding of the Dalit Panthers in 1972. Taking their name and energy from the revolutionary Black Panther Party of Oakland, California, young Dalit writers Namdeo Dhasal, Arjun Dangle, and J. V. Pawar, friends of the protest poet Bagul, recognized that the scattered utterances of Dalit discontent needed a more militant focus. These writer-activists saw themselves as public intellectuals whose mission must be political as well as literary. In their manifesto they attempted to establish their identity and concerns:

Who is a Dalit? Members of Scheduled Castes and Tribes, neo-Buddhists, the working people, the landless and poor peasants, women, and all those who are being exploited politically, economically, and in the name of religion.

Who are our Friends? Revolutionary parties set to break down the caste system and class rule. Left parties that are left in a true sense. All other sections of society that are suffering due to the economic and political oppression.

Who are our Enemies? Power, wealth, price. Landlords, capitalists, moneylenders and their lackeys. Those parties who indulge in religious or casteist politics, and the government which depends on them.

Burning Questions before the Dalits Today. Food, clothing, shelter. Employment, land, (removal of) untouchability. Social and physical injustice.

${ }^{5}$ For a history of the rise of Dalit literature, see Gail Omvedt, 'Literature of Revolt,' and Arjun Dangle, 'Introduction: Dalit Literature Past, Present, and Future,' in Arjun Dangle, ed., Poisoned Bread: Translations from Modern Marathi Dalit Literature, New Edition. Hyderabad: Orient Blackswan, 2009. 
The struggle for the emancipation of the Dalits needs a complete revolution. Partial change is impossible. ${ }^{6}$

In the years following the explosive debut of the Dalit Panthers, autobiography soon rivaled protest poetry and social commentary as the most effective vehicle of expression, empowerment, and outreach for the oppressed people of India.

Dalit literature would be impossible without the example and influence of Babasaheb ("respected father") Ambedkar - father of the modern Dalit human rights movement and a founding father of the Indian republic, its first law minister and chair of the Constitution drafting committee. Born in a military camp as the youngest of fourteen children in the Mahar caste of lowly village servants, Ambedkar made history as the first untouchable to graduate from high school, college, and two of the most distinguished institutions of higher learning outside India, Columbia University in New York City and the University of London. Armed with doctoral degrees in economics and political science and credentialed as a barrister-at-law, Ambedkar returned to India in the 1920s and promptly launched a civil rights movement for untouchables. He fought the Hindu caste system on the streets and in classrooms, courtrooms, government chambers, and the pages of periodicals and scholarly books. Seldom did he take the time to write about himself, but after his death, among his papers was found a handwritten memoir that he likely penned in mid-career in 193536, that he titled Waiting for Visa. ${ }^{7}$

Ambedkar prefaces his account of six traumatic experiences in his childhood and early career with words we may take today as a fitting introduction to the genre of Dalit autobiography:

Foreigners of course know of the existence of untouchability. But not being next door to it, so to say, they are unable to realize how oppressive it is in its actuality. It is difficult for them to understand how it is possible for a few untouchables to live on the edge of a village consisting of a large number of Hindus; go through the village daily to free it from the most disagreeable of its filth and to carry the errands of all and sundry; collect food at the doors of the Hindus; buy spices and oil at the shops of the Hindu Bania from a distance; regard the village in every way as their home - and yet never touch or be touched by any one belonging to the village.

The problem is how best to give an idea of the way the untouchables are treated by the caste Hindus. A general description or a record of cases of the treatment accorded to them are the two methods by which this purpose could be achieved. I have felt that the latter would be more effective than the former. In choosing these illustrations I have drawn partly upon my experience and partly upon the experience of others. I begin with events that have happened to me in my own life. ${ }^{8}$

\footnotetext{
'Dalit Panthers Manifesto (Bombay, 1973)' in Barbara Joshi, ed. Untouchable! Voices of the Dalit Liberation Movement. London: Zed Books, 1986, pp. 145-146.

${ }^{7}$ B.R. Ambedkar. (1993). 'Waiting for visa.' Dr. Babasaheb Ambedkar: writings and speeches. (Ed. V. Moon). Vol. 12, Part I (pp. 661-691). Bombay: Education Department, Government of Maharashtra. And Retrieved from http:/www.columbia.edu/itc/mealac/pritchett/00ambedkar/ txt_ambedkar_waiting.html

${ }^{8}$ Ibid.
} 
Ambedkar writes of his nightmare as an untouchable child who is denied water and threatened with violence and robbery when traveling overnight to visit his father, and how as a young Ph.D. back from the West he was forcibly ejected from lodging and shunned by his own subordinates when his caste was discovered. He follows these accounts with four other incidents of physical abuse and humiliation resulting from the practice of caste exclusion wherever he went. The young Ambedkar did not suffer the grinding poverty that other memoirists describe, due to his father's employment and education, but the repeated discovery that his superior educational and professional achievements were inconsequential to upper caste Hindus produced in Ambedkar a lifelong sense of indignation and a determination to overcome these obstacles for himself and all Dalits. While most of his writings - now filling the fourteen volumes that Vasant Moon edited for the Maharashtra government - can be described as a "general description" of the caste system by a trained social scientist and historian, we are fortunate that Ambedkar left us this trenchant "record of cases" from his own experience.

How have Ambedkar's followers emulated this small beginning with works of sweeping scope and emotional impact?

In 1978, the first full-length Dalit autobiography appeared in Mumbai. The Marathi poet Daya Pawar published Baluta, using for his title the word for the meager payment of grains for the unrelenting slavery of village untouchables as a metaphor for his early life. His graphic presentation of the pervasiveness of deprivation and cruelty in rural village and urban slum life shocked readers at the time.

The Mahars lived in squalid homes, each the size of a henhouse, each hen house having two or three sub-tenants. Wooden boxes acted as partitions. But they were more than that: we stuffed our lives into these boxes. At night temporary walls would come up, made of rags hanging from ropes.

The Mahar men worked as [porters] or laborers. Some worked in the mills and factories. None of the women observed purdah. How could they? They worked harder than the men. They scavenged scraps of paper, rags, broken glass, and iron from the streets, sorted them out and then sold them each morning. And however much their drunkard husbands beat them, they continued to serve them hand and foot, and indulged their addictions.

Born in 1935, Pawar survived the humiliations of a village childhood before moving to the city, where he took a job in a science lab at twenty-one. By the time of his death in 1996, he had won awards for poetry and the autobiography, visited the U.S. on a Ford Foundation Fellowship, served on state educational boards and seen his work translated into many languages. But he refused to present himself as a paradigm for others. When his father died of alcoholism, Pawar destroyed his father's private still. But "deconstructing the entire concept of Mahar machismo which depends on the abuse of women," writes his translator Jerry Pinto, Pawar presents his repeated failures in courtship and marriage and his inability to protect two of his aunts, who are beaten and sold into prostitution, as products of his intermittent lack of self-respect and courage as a man. ${ }^{9}$

${ }^{9}$ Two years after the appearance of Baluta, Pawar's publisher Granthali released Upara, by Laxman Mane. Described as "perhaps the most popular of the Dalit autobiographies" by literary critic G. N. Davy, the Marathi life narrative was published in English in 1997 as Upara - the 
The themes of exclusion, poverty, and misogyny are echoed in different ways in The Outcaste - Akkarmashi by Sharankumar Limbale (Marathi, 1984; English, 2003). Limbale, who would later author the influential critical study, Towards an Aesthetic of Dalit Literature (Marathi, 1996; English, 2004) begins his story, as so many of these autobiographers do, with an unsparing look at his parents:

My mother is an untouchable, while my father is a high caste from one of the privileged classes of India. Mother lives in a hut, father in a mansion. Father is a landlord; mother is landless. I am an akkarmashi (half-caste). I am condemned, branded illegitimate. ${ }^{10}$

Limbale describes himself as the "son of a whore", "bastard", and "rape-child". And as so many of these autobiographers do, Limbale extends the central fact of his life to serve as a metaphor for his extended family, his neighborhood, his caste, and the masses of those who are likewise soiled and damaged by their heritage.

This is the story of my life, an expression of my mother's agony and an autobiography of a community. Being fatherless is as much my fate as it is to be in a general ward [of a hospital] of suffering . . . . My autobiography holds in it the agony of such a life. My experiences are my words. What will remain there if you take experience away from a life? A living corpse. ${ }^{11}$

Yet, as the critic G. N. Davy writes in the introduction to the English translation, "whereas the narrator should be boiling with anger, he is meditating on the very fundamental issues related to social relationships and ethics. It is this detachment, and the ability to turn away from the personal, that makes Akkermashi a disturbing life narrative."12 Yet it also creates a sense of awe, perhaps akin to that of reading of the Stoic Epictetus's imperturbability as his leg is broken by his sadistic master: "I have said it would break. Now it is broken."

The first significant autobiography by a Dalit woman appeared two years after Limbale's work. Babytai Kamble's The Prisons We Broke (Marathi Jina Amucha, 1986; English, 2008, also translated The Way We Live) displays her power as a writer and as a survivor whose book "came out of the furnace of the suffering we underwent. Each word in it is a shoot of the truth that has sprouted in my heart." We learn of her humble beginnings and struggles on each page of her work, but we must wait for two interviews she gave to fellow women activists after her book was out to grasp

outsider by Sahitya Akademi. Like Baluta, this autobiography was awarded for its depiction of the poverty and activism of marginalized people, particularly the nomadic tribes of Maharashtra, the author did not foreground the suffering of Dalit women as Pawar did. In 2013, Mane's reputation was stained by his arrest for alleged sexual exploitation of women employees of the school he ran.

${ }^{10}$ Sharankumar Limbale. (2015). The Outcaste - Akkarmashi. Bhoomkar, S, Translator. Devy, G. N. Introduction. New Delhi: Oxford University Press, p. ix.

${ }^{11}$ Ibid, p. xxiv. One can see why the honorific Babasaheb, 'revered father', applied to one of their own, became so important to Dalits whose own fathers were perennially marginalized and discredited.

${ }^{12}$ Ibid, p. xxv. 
her achievement. Maya Pandit, her translator, begins the interview offered in the second edition of Prisons with the surprising observation that Kamble has made very few references to her personal life in the book! "Can you tell us a little more about yourself?" The author replies, "I really find it very difficult to think of myself outside of my community," and then turns immediately to the sacrifices other women made to send their children to school "because their Baba [Ambedkar] told them to do it."

In spite of Kamble's great humility and reticence, we learn of her success in business as she began early in life selling loose grapes recovered from the market and then expanded her inventory over the years to sell vegetables and other items within the Maharwada. Eventually she and her husband were running a successful neighborhood grocery store when Meenakshi Moon and Urmila Pawar visited to interview her for their book, We Also Made History. She explains how, tending the store over twenty years, she would read the newspapers donated to wrap groceries and write her observations and reflections in secret notebooks she kept behind the counter. She eventually admitted to their existence when a visiting scholar, Maxine Berntson, questioned her closely. Encouraged to publish them, Kamble submitted them serially to the women's magazine Stree and eventually assembled and published them as the autobiography we have now. Meanwhile, Baby Kamble gave birth to ten children, seven of whom survived to adulthood, and became active in Dalit politics. She joined the local Mahila Mandal, a woman's service organization, and founded a governmentaccredited residential school for Dalit orphans — all while dodging her husband's blows and keeping up the store.

The intricate but full-throated intersectionality of Babytai Kamble's account of women's simultaneous struggles with poverty (class), marginalization (caste), and misogyny (patriarchy) is surely a breakthrough for feminist writing in India. Yet Kamble would be the last to admit that she was a pioneer. Indeed, the most touching paradox of her achievement is the credit and devotion she bestows on Babasaheb Ambedkar for her inspiration and that of her generation of Mahar women. She concludes the preface of the first edition of her book with what may be considered a bhajan or devotional song to her savior:

I most humbly offer my eternal gratitude at the feet of that great man and bow my head at his feet. All I can manage to say is: O Bhim, you have been our great Mother, and we will never be able to repay the enormous debt we owe you. We are eternally grateful to you. I am just a small flower that has bloomed in some obscure outskirts of a village. I offer this humble gift, my book, a tiny flower, at your feet.

And toward the end of the book, breaking into verse:

What do I have, Bhima? What can I offer to you ...

Except for flowers? You gave voice to our suffering souls.

Each flower that I offer is nothing but a burning grief

With tears flowing from my eyes, I wash your feet.

The fire raging in my heart has ignited this flame,

Through the flickering of these flames, All I see is Buddha and Bhim. 
Paradoxically, given Ambedkar's repudiation of Hindu devotionalism, one may hear its echo here. In Bhagavad Gita 9.26 Lord Krishna accepts "with devotion a leaf, a flower, a fruit, or even water" from one who has little else. But this sentiment is not exclusive to Indian religion. One also hears Jesus' praise for the fallen woman who washed his feet with her tears, dried them with her hair, and anointed them with costly oil: "Go in peace" (Luke 7.44-50). But lest her bhajan be seen as a capitulation to Vaishnavite spirituality or wider religious patriarchy, Kamble's heartfelt tribute is intoned to Ambedkar, the great Mother to all who struggle.

A new world of exclusion and pain was revealed to readers with the release of Laxman Gaikwad's Uchalya in 1987 (Marathi; English The Branded, 1998). Categorized as an autobiographical novel, the book is pathbreaking in its depiction of the lives of the involuntary criminals forced into lives of thieving by laws dating back to the British Criminal Tribes Act of 1871. Members of the Uchalya ("pilferer") tribes, found throughout India, were "notified" under the law as "addicted to the systematic commission of non-bailable offences" and thus unworthy of any "settled contribution to society." The Criminal Tribes Act was repealed in 1949 only to be replaced by new laws requiring police to investigate a suspect's "criminal tendencies." The denotified tribes were reclassified by the Indian government as "habitual offenders" in 1959. Gaikwad's extraordinary career as a social worker, anti-caste activist and awardwinning writer begins as his grade school education is constantly interrupted by close encounters with the violent civilian and uniformed guardians of upper caste society. In contrast to the harrowing school stories in other Dalit autobiographies, Gaikwad's description of the training of Uchalya children is disturbing:

Now Bhagwan-Anna and Samhu Bhau started accompanying Manik-Dada on thieving trips to take charge to stolen bundles. Anna and Bhau were, otherwise, quite capable of doing odd jobs. But so branded and distrusted was our community socially that ... nobody employed Anna and Bhau. They had so far never indulged in thieving. Now, however, they started accompanying Dada on thieving trips. They were made tough with the usual session of beating.

In our community there are gangs who undertake the training of apprentices to develop their thieving skills. In every society, there are teachers who teach students in schools and parents who beat their offspring to make them learn. In our community, however, everything is topsy-turvy.

We have four kinds of thieving skills: Khistand matne - picking pockets. Chappal, muthal aanane - stealing footwear and bundles. Paddu ghalane - deception. And Uthewaari - deception by sleight of hand while engaging persons in conversation, e.g. substituting spurious gold for the genuine. ${ }^{13}$

The first successful Dalit autobiographies grew out of the Dalit Panther/Dalit Sahitya movement in Maharashtra, home of Ambedkar's Mahar caste and of the Marathi language. Thus, the texts we have surveyed so far were originally published in Marathi. Yet significant Dalit literary movements have emerged in other language

${ }^{13}$ Laxman Gaikwad. (1998). The Branded: Uchalya. New Delhi: Sahitya Akademi, p. 10. 
communities that produced remarkable autobiographies, some of which are now translated into English. First of this group is the Karnataka-based poet, playwright, public intellectual and elected official Siddalingaiah's immensely entertaining $A$ Word with You, World (Kannada Ooru Keri, 1996; Ooru Keri 2, 2009; English 2013). It may seem insensitive to describe a work of protest literature as entertaining. But readers of Siddalingaiah will readily admit that even in the midst of harrowing events and cruel encounters, this author is capable of lightness and irony. "Siddalingaiah takes a Chaplinesque view of hunger and discrimination, and his humor and irreverence appeal to a wide readership," writes his translator S. R. Ramakrishna.

It is bittersweet to speak of Siddalingaiah now, as Covid-19 took his life just weeks ago (June 11, 2021), but it is perhaps all the more fitting to praise him for his gift to "the world." The combining of the three installments of the original narrative "Village Corner" (Ooru Keri and Ooru Keri 2 and 3) was the idea of S. Anand, the indefatigable founder-editor of Navayana Publishing, who suggested a line from Siddalingaiah's poem Maatada Beku for the English title:

I must have a word with you

O cactuses and thorny plants;

I must put a question to the moon who borrows his light;

I should free the beautiful rose from thorns.

Wells are waterless and ministers speechless

Constables move about like thorny bushes,

O world, I must have a word with you. ${ }^{14}$

Again, in this kinetic sequence of intimate vignettes we encounter blinding hunger and disease, confinement and squalor in village and city slums, violent death by suicide and murder, stealing, pranks that go awry, and relationships that degrade and threaten. But here, perhaps more than in the books we have seen so far, we also meet kindly teachers, heartwarming camaraderie, enduring friendships, improbable benefactors, role models among elected officials, and the author's unsinkable curiosity and goodwill toward others. In his career, Siddalingaiah became the face of Kannada literature: leader of the Dalit Bandaya movement and founder of the Dalit Sangharsh Samithi. A Member of the Legislative Assembly in 1988 and 2006, he became chairman of the Kannada Development Authority. Through it all, his eulogizers of all recall him as "a warm and compassionate human being."

Omprakash Valmiki's Joothan: An Untouchable's Life was written and published in Hindi in 1997 and translated and published in English in 2003. Its translator, Arun Prabha Mukherjee, identifies Valmiki as one of the first Hindi writers to identify himself with the Dalit literature that first spoke in Marathi. Yet his may also be seen as a carrier of the spirit of this movement out to other language communities that share the fight against caste: speakers and writers in Kannada, Tamil, Telugu, Malayalam, Gujarati, Punjabi and English. Joothan means the "table scraps-leftovers" at best, "garbage" and "compost" at worst - that untouchables line up at the back doors of

${ }^{14}$ Siddalingaiah. (2013). A Word with you, world. New Delhi: Navayana Publishing, p. 9. 
upper caste homes to collect and take home to their hungry families. After weddings and holidays, the leftovers may retain some flavor of the savory or sweet cuisine of Hindu high tables; the children clamor for this holiday joothan. But more often the leftovers are the inedible parts of the meal that remained on the plates in the end, and hungry children must eat this as well. Like the terms baluta, akkarmashi, and Uchalya, which have been left untranslated in the titles of these works, joothan ushers us into the world of the Dalit experience, sometimes because the terms are untranslatable in English, but also perhaps because the author and translator hope that an unfamiliar word will help the visitors to acknowledge their distance from the common and troubling experiences of their hosts. In each case the foreign word serves as a symbol and a metaphor for that distance.

For Omprakash Valmiki the signaling of a name had specific importance. While Valmiki was the Brahmin poet of the Ramayana, the Valmikis of northern India are the caste of scavengers and sewer workers, lowest of the low, also known as Bhangis and Chuhras. Omprakash is constantly reminded by teachers and employers that, whatever his educational attainments, he will always be a Chuhra. When he enters the workforce and faces pressure from friends to change his name Valmiki, he wears it as a badge of honor. Engaged to be married, his wife informs him that she will keep her maiden name. The wedding invitations omit his surname, as does the publisher of his first poem and article in a liberal magazine. When an officer's wife asks his wife, "Brahmin?" as the two families socialize on the train, Valmiki interrupts, saying "Bhangi" to make no mistake. Summing up the challenge of assertion versus passing, Valmiki makes an ironic comparison:

Identity and recognition - these two words say a lot by themselves. Ambedkar was born in a Dalit family. But Ambedkar is a Brahmin caste name; it was a pseudonym given by a Brahmin teacher of his. When joined with Bhimrao, however, it became his identity, completely changing its meaning in the process. Today Bhimrao has no meaning without Ambedkar. ${ }^{15}$

When Ambedkarites greet one another with Jai Bhim, "victory to Ambedkar," they do not think "Brahmin" or "Bhima," the strongest of the Pandava warriors in the Mahabharata. They think only of Ambedkar, champion of the Dalits.

In The Weave of My Life: A Dalit Woman's Memoirs, Urmila Pawar offers another powerful testament to the emergence of women in the Ambedkar movement. During his first mass protest, the fight for access to drinking water at Mahad in 1927, Ambedkar invited Dalit women to become movement leaders in their own right. And Pawar and Meenakshi Moon tell the story of this evolution in the first half of their book We Also Made History. In her autobiography, titled Aaydan! in the Marathi original, Pawar, like her predecessors, uses a term drawn from the daily lives of village Dalits to symbolize both hardship and assertion. In the Konkan region of Maharashtra, aayden refers to the bamboo baskets that Dalit women wove for income. "My mother used to weave aaydans. I find that her act of weaving and my act of writing are organically linked.

${ }^{15}$ Omprakash Valmiki. (2003). Joothan: An Untouchable's life. New York: Columnia University Press, p. 152. 
The weave is similar. It is the weave of pain, suffering, and agony that links us." 16 Pawar also weaves together the lives of her extended family and the widening circle of friends and professional colleagues who join her in founding numerous women's organizations for social work, political activism, and literary expression. Born in 1945, Urmila was introduced to Buddhism at the age of twelve as Mahar families followed Ambedkar into the new faith. Like Baby Kamble, Pawar grapples with the dominance and misogyny of men in the community and in the family, making clear to all that a woman has equal dignity and equal rights. She chooses and marries for love over her family's objections, but later endures her husband's drinking and jealousy of her success. Her ten published works and literary prizes have placed her in the forefront of Marathi authors.

In the weave of Urmila Pawar's life we meet again our friends Vasant and Meenakshi Moon, Meenakshi's sister Hira and her husband Namdeo Nimgade, Daya Pawar, Eleanor Zelliot, Baby Kamble, Maxine Berntson, and Dr. Balchandra Mungekar, the first Dalit vice chancellor of the University of Mumbai, a future member of the central planning committee in the Delhi government, and another generous host of mine in Mumbai. As a regular visitor to the landmarks of the new Dalit literary canon, I began to feel my way around, airfare to India no longer required.

The childhood narratives in Moon's Growing up Untouchable in India and Nimgade's In the Tiger's Shadow take us back to the neighborhoods of Nagpur, where throngs of Dalits converged in 1956 for the great Buddhist conversion. Both authors tell of their life-changing encounters with Babasaheb Ambedkar, the "tiger" of the untouchables. For Moon, who trembled and stood mutely as a schoolboy, badgered by a Brahmin teacher (“Oh, speak, little man, speak!”) and ridiculed by his upper -caste classmates, Moon stood confidently before the visiting Ambedkar a few years later. Thumbing through the handwritten magazine Moon and his friends presented to the guest, Ambedkar questioned the young activists about their work. But Moon had his own questions about Buddhist philosophy and marriage rituals. The great man explained rebirth ("without being extinguished, the spark from the candle arises in another place") and acknowledged the need for new marriage customs among the Buddhists. Suddenly he held up the magazine and asked, "Who has written this article?" "That is my article," Moon declared, admitting in his memoir that "before such a great man as Babasaheb I had no fear." Years later, the magazine was returned with Ambedkar's comments: "Excellent. Well worthy of emulation."17

Dr. Namdeo Nimgade's In the Tiger's Shadow (temporarily out of print) offers a fitting way to end our survey. Nimgade grew up in the same Mahar vastis as Moon, and like his future brother-in-law, was a fearless adventurer on the streets and a diligent student in class. Both were brilliant and vigorous converts to the new Dalit assertion, and both had dramatic encounters with Ambedkar. Nimgade, who would become the second Dalit after Ambedkar to earn a Ph.D. in the United States (University of

\footnotetext{
${ }^{16}$ Urmila Pawar. (2008). The weave of my life: A Dalit woman's memoirs. New York: Colombia University Press, p. ix.

${ }^{17}$ Moon, pp. $147-148$.
} 
Wisconsin, Madison, 1962, in agronomy), was also the first Dalit to interact with Dr. Martin Luther King on the plight of the untouchables. In a speech on campus King reported his trip to India and Nehru's claim that untouchability had been eliminated. Nimgade, who had just passed his oral examinations, stood up during the question period and respectfully informed King and a very large audience of the continuing role of Dr. B. R. Ambedkar and his followers to achieve the result Nehru had claimed - and how far there still was to go. That night many African Americans called to thank the Indian student for his courage, and at graduation time, the Wisconsin State Journal ran the headline "'Untouchable' Gains Ph.D. - Indian's Struggle Worth Effort."

Nimgade was a one of Ambedkar's favorite young followers during his final years, and Nimgade devotes several chapters to their private conversations in New Delhi. In one exchange, Ambedkar strongly urged Namdeo to delay marriage until his education was complete. But Nimgade had visited that day expressly to announce his engagement and to seek Babasaheb's blessing. "Baba, will you please write a message of good will for my wedding." Ambedkar demurred, saying that both of his hands were aching so much from constant writing that had been unable to use them for three days. Yet he had an idea. "Go to my study and there you will find a Marathi version of Emperor Ashoka's edicts concerning Buddhism. Please consider these my good wishes, which you can read out to everyone. Please give one to the bride's family and keep one for yourself. In the near future we will all embrace Buddhism. But we must prepare for that now."

Namdeo was overjoyed. And the final words of Ambedkar's Marathi excerpt of Ashoka's edicts "carved on a rock some 2,200 years ago" were read at the weddingand may serve as a proper benediction for our survey:

Emperor Ashoka desires that all the people in his empire live in happiness and interact with each other in peace and amity. Do not kill. All great religions should teach tolerance and purity of mind. Everyone should contribute to the common good according to their means. Even the poor, who do not have the means to donate, can also practice tolerance, good character, gratefulness, and faith. However, all good deeds are in vain if performed without faith and purity of mind. There is no greater gift than faith, abide by the Dhamma. ${ }^{18}$

\section{References}

Ambedkar, B.R. (1993). Waiting for visa. Dr. Babasaheb Ambedkar: writings and speeches. (Ed. V. Moon). Vol. 12, Part I (pp. 661-691). Bombay: Education Department, Government of Maharashtra. Retrieved on 9 September 2021 from http://www.columbia.edu/itc/mealac/ pritchett/00ambedkar/txt_ambedkar_waiting.html.

Anand, M.R. (1940). Untouchable. London: Penguin Books.

Dangle, A. (2020). Poisoned bread. Hyderabad: Orient BlackSwan.

Gaikwad, L. (2005). The branded - Uchalya. New Delhi: Sahitya Akademi.

${ }^{18}$ Nimgade, pp. $189-190$. 
Joshi, B. (1986). Untouchable! Voices of the Dalit liberation movement. London: Zed Books. Kamble, B. (2018). The prisons we broke. Second Edition. Hyderabad: Orient BlackSwan. Limbale, S. (2004). Towards an aesthetic of Dalit literature. Hyderabad: Orient BlackSwan. - (2015). The outcaste - Akkarmashi. New Delhi: Oxford University Press.

Mane, L. (1997). Upara - The Outsider. New Delhi: Sahitya Akademi.

Moon, V. (2001). Growing up untouchable in India: a Dalit autobiography. Lanham, MD: Rowman \& Littlefield.

Nimgade, N. (2010). In the tiger's shadow: the autobiography of an Ambedkarite. New Delhi: Navayana.

Pawar, D. (2015). Baluta. New Delhi: Tiger Publishing.

Pawar, U. (2009). The weave of my life: a Dalit woman's memoirs. New York: Columbia University Press.

Siddalingaiah. (2013). A word with you, world. New Delhi: Navayana. 